\title{
Tsunami Hazard Assessment of Coastal South Africa based on Mega-earthquakes of Remote Subduction Zones
}

Andrzej Kijko', Ansie Smit² ${ }^{2}$, Gerassimos A. Papadopoulos ${ }^{3}$, Tatyana Novikova ${ }^{4}$

(1) University of Pretoria Natural Hazard Centre, Africa, Department of Geology, University of Pretoria, Private Bag X20, Hatfield, Pretoria,0028, South Africa Pretoria, South Africa; e-mail: andrzej.kijko@up.ac.za;

(2) University of Pretoria Natural Hazard Centre, Africa, Department of Geology, University of Pretoria, Private Bag X20, Hatfield, Pretoria,0028, South Africa Pretoria, South Africa; e-mail:ansie.smit@up.ac.za

(3) Institute of Geodynamics, National Observatory of Athens, P.O. Box 20048 Thissio 11810, Athens, Greece, e-mail: papadop@noa.gr

(4) Institute of Geodynamics, National Observatory of Athens, P.O. Box 20048 Thissio 11810, Athens, Greece; e-mail: tatyana@noa.gr

*Corresponding author: University of Pretoria Natural Hazard Centre, Africa, Department of Geology, University of Pretoria, Private Bag X20, Hatfield, Pretoria,0028, South Africa Pretoria, South Africa; Tel: +27 12420 2282; e-mail: ansie.smit@ up.ac.za; ORCID: 0000-0003-0315-0875

\begin{abstract}
After the mega-earthquakes and concomitant devastating tsunamis in Sumatra (2004) and Japan (2011), we launched an investigation into the potential risk of tsunami hazard to the coastal cities of South Africa. This paper presents the analysis of the seismic hazard of seismogenic sources that could potentially generate tsunamis, as well as the analysis of the tsunami hazard to coastal areas of South Africa. The subduction zones of Makran, South Sandwich Island, Sumatra, and the Andaman Islands were identified as possible sources of mega-earthquakes and tsunamis that could affect the African coast. Numerical tsunami simulations were used to investigate the realistic and worst-case scenarios that could be generated by these subduction zones. . The simulated tsunami amplitudes and run-up heights calculated for the coastal cities of Cape Town, Durban, and Port Elizabeth are relatively small and therefore pose no real risk to the South African coast. However, only distant tsunamigenic sources were considered and the results should therefore be viewed as preliminary.
\end{abstract}

Key words: seismic hazard assessment, tsunami hazard, tsunamigenic source, South Africa

\section{Introduction}

The death and destruction in the wake of the mega-earthquakes and tsunamis of 26 December 2004 in Sumatra and 11 March 2011 in Tōhoku, Japan, serve as a reminder of the necessity for timely assessment of the potential tsunami hazard faced by susceptible coastlines. It is accepted generally that the extremely high death toll could have been avoided if an effective Indian Ocean tsunami warning system had been in place, similar to the Pacific Tsunami Warning Center (PTWC) in Hawaii and the National Tsunami Warning Center (NTWC) in Alaska. In response to the tragedy in Sumatra, the Indian Ocean Tsunami Early Warning System (IOTWS) was created.

The Intergovernmental Oceanographic Commission of UNESCO (IOC-UNESCO) was tasked with coordinating the establishment of the early warning system. In June 2005, during the 23rd session of the IOC, the Intergovernmental Coordination Group for the Indian Ocean Tsunami Warning and Mitigation System (ICG/IOTWS) was formally established. Today the group has 28 member states, including South Africa. Many countries participate through national tsunami warning centres. However, three Regional Tsunami Service Providers (Australia, India and Indonesia) are the primary source of tsunami advisories for the Indian Ocean 
(http://iotic.ioc-unesco.org/indian-ocean-tsunami-warning-system/tsunami-early-warning-centres/57/regionaltsunami-service-providers; last access 16 Oct. 2017; see also Thomalla and Larsen, 2010).

The 2004 event served to renew research interest into the mega-transoceanic seismic and tsunami hazard the Indian Ocean is facing. Most relevant research focuses on individual countries or regions, with two notable exceptions. A report by Berryman et al. (2013) was published by the Global Earthquake Model (GEM) initiative and provides a detailed description of subduction zones worldwide, as well as estimates of maximum possible magnitudes. A study by Burbidge et al. (2009) focussed specifically on the Indian Ocean, with a panel of experts compiling a report on the potential tsunami effect of particular subduction zones in the coastal cities of the Indian Ocean. It was recommended that all the susceptible countries identified by this study invest in comprehensive and thorough tsunami hazard analyses, which should include regional inundation models.

In South Africa, there is a significant lack of recorded information on tsunamis that have affected the country and, currently, only five events have been identified as tsunamis (Table 1). The most recent event, attributed to the 2004 mega-transoceanic tsunami, affected parts of the eastern coast of Africa. In South Africa, maximum wave heights between $0.75 \mathrm{~m}$ and $0.9 \mathrm{~m}$ were observed at Simon's Bay, Cape Town, and Saldanha, with two drownings being reported. Of the tsunami events listed in Table 1, this event is the only one for which there is conclusive evidence. The event of 1809 is usually associated with the magnitude 6.3 Milnerton earthquake that is commonly believed to have triggered a submarine landslide (Hartnady and Botha, 2007). As regards the rest of the events, the sources of the abnormal wave heights are unknown, as these waves cannot be associated with any recorded local or distant earthquakes at this time. Possible local tsunami sources, which could have contributed to such events include the steeply sloped sediments on the Western Cape continental margin (Dingle, 1980; Dingle et al., 1987; Dingle and Robson, 1992; Wefer et al., 1998) and the possible existence of mud volcanoes south of the Walvis Ridge (Ben-Avraham et al., 2002). Although a recent study by Salzmann and Green (2012) dismissed the possibility of local tsunamis being attributable to landslide events on the northern KwaZulu-Natal coastline, questions remain over the likelihood of submarine landslides in the southern and south-eastern coastline of South Africa. However, owing to the inferior quality of the available data, these events were excluded from consideration in our analyses.

Table 1. Observed tsunami and tsunami-like events in South Africa.

\begin{tabular}{|l|l|l|l|l|}
\hline \multicolumn{1}{|c|}{ Date } & \multicolumn{1}{|c|}{ Location } & \multicolumn{1}{c|}{ Source } & \multicolumn{1}{c|}{ Comments } & \multicolumn{1}{c|}{ References } \\
\hline $1809-12-04$ & Milnerton & $\begin{array}{l}\text { Earthquake/ } \\
\text { Landslide }\end{array}$ & $\begin{array}{l}\text { Fish observed in the } \\
\text { streets of Cape } \\
\text { Town }\end{array}$ & $\begin{array}{l}\text { Hartnady and } \\
\text { Botha (2007) }\end{array}$ \\
\hline $1883-08-24$ & Port Elizabeth & $\begin{array}{l}\text { Krakatau volcanic } \\
\text { eruption }\end{array}$ & $\begin{array}{l}\text { Maximum wave } \\
\text { height } \\
\text { approximately 1.4 m }\end{array}$ & Choi et al., 2003 \\
\hline $1969-08-26$ & $\begin{array}{l}\text { Dwarskersbos, West } \\
\text { Coast }\end{array}$ & Unknown & $\begin{array}{l}\text { Abnormal wave } \\
\text { Run-up approx. 5m }\end{array}$ & $\begin{array}{l}\text { Council for } \\
\text { Geoscience }\end{array}$ \\
\hline $1981-05-11$ & Agulhas Bank & Slumping (?) & - & $\begin{array}{l}\text { Council for } \\
\text { Geoscience }\end{array}$ \\
\hline $2008-08-(20-21)$ & Cape West Coast & Unknown & Abnormal wave & $\begin{array}{l}\text { Council for } \\
\text { Geoscience }\end{array}$ \\
\hline $2004-12-26$ & $\begin{array}{l}\text { Eastern coast of South } \\
\text { Africa (e.g. Port } \\
\text { Elizabeth, Port }\end{array}$ & $\begin{array}{l}\text { 26 December } \\
\text { 2004, } \\
\text { Sumatra-Andaman } \\
\text { Nolloth) and as far as } \\
\text { Saldanha Bay, Cape } \\
\text { Town, Simon's Bay) }\end{array}$ & $\begin{array}{l}\text { Maximum wave } \\
\text { heights of 0.75- } \\
\text { 0.9 m at Simon's } \\
\text { Bay, Cape Town, } \\
\text { and Saldanha; two } \\
\text { people drowned }\end{array}$ & $\begin{array}{l}\text { Joseph } \text { et al. } \\
\text { (2006); Okal and } \\
\text { Hartnady (2009) }\end{array}$ \\
\hline
\end{tabular}

The aim of the current study was to assess the potential tsunami hazard to the South African coastline. For this purpose, we assessed earthquake recurrence parameters for each of the identified tsunamigenic source zones. 
Provision was made in all the calculations for the incompleteness of the earthquake catalogues, the uncertainty of the earthquake magnitude determination, and the uncertainty of the applied earthquake occurrence model.

Estimated parameters were used to calculate the maximum expected wave height through the numerical simulation of tsunamis for "worst-case" and "realistic" scenarios. The worst-case scenarios depict hypothetical, yet possible scenarios, while realistic scenarios concern particular tsunami events that affected the coastline in the past. In our case, worst-case scenarios include mega-earthquakes associated with various subduction zones around the Indian Ocean, while a realistic scenario is the large tsunami produced by the mega-earthquake of 1833 generated in the Sumatra subduction zone. The aim was to evaluate the maximum possible impact, based on the available information and the results of several numerical tests. Other authors have followed a similar approach in their research, including Burbidge et al. (2009), González et al. (2009), Power et al. (2007), Sørensen et al. (2012), and Brizuela et al., (2014).

After the brief introduction in Section 1, a description of the identified tsunamigenic sources and the applied methodologies is presented in Section 2. The results of the earthquake and tsunami hazard assessment are provided in Sections 3 and 4, with the discussion and conclusions provided in Section 5.

\section{Identification of source zones}

According to Burbidge et al. (2009), the subduction zones of the South Sandwich Islands, Sumatra, and, to a lesser extent, the Andaman Islands are considered the main contributors to the tsunami hazard to the coastal cities of South Africa. In this paper, we discuss zone-characteristic seismic hazard analysis of the subduction zones of Andaman, Sumatra Island, a section of the Sunda Arc in Indian Ocean, the South Sandwich Islands in the southern Atlantic Ocean, and the Makran subduction zones in the Persian Gulf and the Gulf of Oman (Figure 1). Okal and Synolakis (2008) conducted similar analysis of the far-field tsunami hazard from mega-thrust earthquakes in the Indian Ocean related to the seismic sources located at the boundaries of the 2004 SumatraAndaman rupture. Such sources run along the southern coast of Sumatra and in the Andaman-Myanmar region, along the Makran coast of Pakistan and Iran, and farther along the southern coast of Java. These authors investigated how the variation in the earthquake focal parameters and the mode of seismic slip could affect the influence of far-field tsunamis. They concluded that if the seismic moment of the earthquake remained the same, the tsunami characteristics in the far-field domain appeared remarkably robust with respect to the variations in the properties of the parent earthquakes.

In the current study, following Burbidge et al. (2009), we assumed that the distant earthquake sources of Makran, the South Sandwich Islands, and Sumatra-Andaman were subduction zones that could generate megatsunamis that could affect the coastal areas of South Africa. Near-field tsunami-generating sources were excluded from the analysis because of a lack of confidence in the information. During the last couple of centuries, Java trench subduction zone has exhibited relatively low seismic activity. The catalogue of seismic events for this region does not provide any earthquake that generated a trans-oceanic tsunami. Even the devastating local tsunamis in 1994 and 2006 failed to reach the shores of the African continent. (Okal and Synolakis, 2008). Java trench is known from its very low, less than $1 \%$ seismic coupling, the ratio of seismic energy release by an earthquake to the total energy accumulated. It suggests that most of the accumulated tectonic energy in the Java trench is released aseismically, by aseismic deformation, as e.g. fault creep (Ruff and Kanamori, 1980; Javier et al., 1993; Ruff and Tichelaar, 1996; Okal and Synolakis, 2008 and references therein). The subduction zone of Java was therefore not included in our analysis of the Sumatra-Andaman tsunamogenic zone. However, the potential to generate mega-tsunami by Java trench is worth to study as a separate issue, due to the potential socio-economic effect of tsunami in the area. 


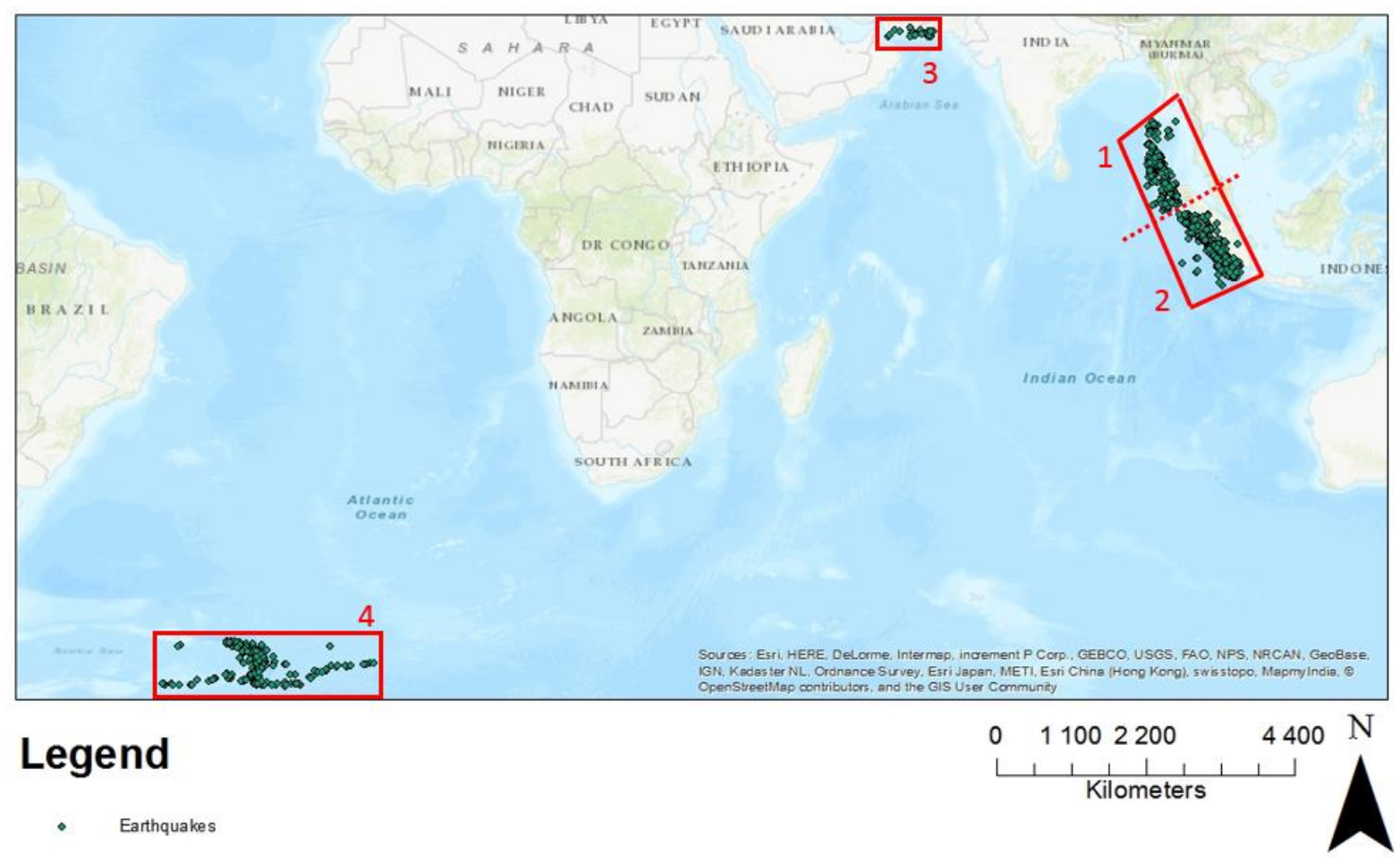

Figure 1. The four tsunamigenic subduction zones considered to have the potential to generate mega-tsunamis that could affect the South African coast: (1) Andaman Subduction Zone, (2) Sumatra Island, (3) Makran, and (4) South Sandwich Islands.

\section{Seismic Hazard Assessment}

As the applied procedure for tsunami hazard assessment requires only information on the distribution of earthquake magnitudes, our analysis of the seismic hazard is limited to the assessment of the respective magnitude exceedances for each of the four identified tsunamigenic sources.

In terms of moment magnitude $M_{W}$, the seismic event catalogues used for the South Sandwich Islands, Sumatra Island, and the Andaman subduction zones were collected from the International Seismological Centre - GEM (ISC-GEM) historical (Version 1.0) and complete (Version 2.01) catalogues (Storchak et al., 2013). The catalogue from Karimiparidari et al. (2013) was used for the Makran subduction zone. Table 2 presents a summary of each of the applied seismic catalogues, which include geographical coordinates, time span, number of events, level of completeness, as well as the maximum observed magnitudes for each of the identified regions. The geographical coordinates were taken from Berryman et al. (2013), with the exception of the South Sandwich Islands, for which the investigated area was increased to include more events.

The seismic recurrence parameters, the mean annual seismic activity rate $\lambda$, and the Gutenberg-Richter $b$-value ( $b=\beta \ln (10)$ ) were estimated by using the maximum likelihood procedure (MLE), as defined in Kijko et al. (2016). We made provision for the incompleteness of the data and the uncertainty associated with the magnitude estimation, as well as the uncertainty of the applied earthquake occurrence models. Aleatory uncertainty in the earthquake occurrence models is introduced by assuming that both $\lambda$ and the $b$-value are random variables, each described by the gamma distribution. The approach results in the replacement of the classic frequencymagnitude Gutenberg-Richter relation and the Poisson distribution, describing the temporal earthquake occurrence of events, by the mixture-gamma distributions (Benjamin, 1968; Campbell, 1982, 1983).

Table 2. Summary of earthquake event catalogue used for the Makran, South Sandwich Islands (SSI), Sumatra Island, and the Andaman subduction zone.

\begin{tabular}{|l|c|c|c|c|}
\hline & Makran & SSI & Sumatra Island & Andaman \\
\hline Coordinates & {$\left[24.38^{\circ} \mathrm{N} ; 57.06^{\circ} \mathrm{E}\right]$} & {$\left[40.00^{\circ} \mathrm{S} ; 63.00^{\circ} \mathrm{W}\right]$} & {$\left[8.17^{\circ} \mathrm{S} ; 96.20^{\circ} \mathrm{E}\right]$} & {$\left[1.35^{\circ} \mathrm{N} ; 92.07^{\circ} \mathrm{E}\right]$} \\
\hline
\end{tabular}




\begin{tabular}{|c|c|c|c|c|}
\hline & $\begin{array}{c}\text { to } \\
{\left[26.05^{\circ} \mathrm{N} ; 65.03^{\circ} \mathrm{E}\right]}\end{array}$ & $\begin{array}{c}\text { to } \\
{\left[10.00^{\circ} \mathrm{S} ; 55.00^{\circ} \mathrm{W}\right]}\end{array}$ & $\begin{array}{c}\text { to } \\
{\left[1.35^{\circ} \mathrm{N} ; 104.58^{\circ} \mathrm{E}\right]}\end{array}$ & $\begin{array}{c}\text { to } \\
{\left[13.72^{\circ} \mathrm{N} ; 96.20^{\circ} \mathrm{E}\right]}\end{array}$ \\
\hline Time span & $1438-2002$ & 1921-2011 & $1681-2011$ & $1837-2011$ \\
\hline $\begin{array}{l}\text { Historic Catalogues } \\
\text { - } \quad \text { Date } \\
\text { - Number of events } \\
\text { - } \quad \text { Level of } \\
\text { completeness } \\
\text { - } \quad \begin{array}{l}\text { Standard error in } \\
\text { magnitude }\end{array} \\
\text { - Maximum } \\
\text { magnitude } \\
\text { observed }\end{array}$ & $\begin{array}{ll}\text { - } & 1438-1969 \\
\text { - } & 4 \\
\text { - } & 6.0 \\
\text { - } & 0.2 \\
\text { - } & 8.0\end{array}$ & $\begin{array}{ll}\text { - } & 1921-1969 \\
\text { - } & 2 \\
\text { - } & 7.5 \\
\text { - } & 0.3 \\
\text { - } & 8.1 \\
\text { - } & \end{array}$ & $\begin{array}{ll} & 1681-1969 \\
\text { - } & 10 \\
\text { - } & 7.5 \\
\text { - } & 0.3 \\
\text { - } & 9.0 \\
\text { - } & \end{array}$ & $\begin{array}{ll}\text { - } & 1837-1969 \\
\text { - } & 5 \\
\text { - } & 7.5 \\
\text { - } & 0.3 \\
\text { - } & 7.9\end{array}$ \\
\hline 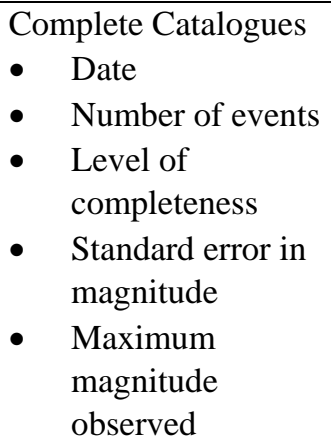 & $\begin{array}{ll}\text { - } & 1970-2002 \\
\text { - } & 23 \\
\text { - } & 4.4 \\
\text { - } & 0.1 \\
\text { - } & 5.5\end{array}$ & $\begin{array}{ll}\text { - } & 1970-2011 \\
\text { - } & 269 \\
\text { - } & 5.5 \\
\text { - } & 0.1 \\
\text { - } & 7.4\end{array}$ & $\begin{array}{ll}\text { - } & 1970-2011 \\
\text { - } & 281 \\
\text { - } & 5.5 \\
\text { - } & 0.1 \\
\text { - } & 8.5\end{array}$ & $\begin{array}{ll}\text { - } & 1970-2011 \\
\text { - } & 213 \\
\text { - } & 5.5 \\
\text { - } & 0.1 \\
\text { - } & 9.0\end{array}$ \\
\hline $\begin{array}{l}\text { Maximum observed } \\
\text { magnitude }\end{array}$ & 8.1 & 8.1 & 9.0 & 9.0 \\
\hline
\end{tabular}

An unbiased estimator of the zone-characteristic (seismogenic source) maximum-possible earthquake magnitude $m_{\max }$ was determined by using the parametric procedure, hereafter referred to as Kijko-Sellevoll-Bayes (K-SB), (Kijko and Singh, 2011) for the subduction zones of South Sandwich Island and Sumatra. However, the nonparametric Gaussian (N-P-G) procedure provides more reliable $m_{\max }$ estimates for the Makran and Andaman subduction zones. Non-parametric methods make the least number of assumptions about the underlying model distribution (Kijko, 2004) and prove useful in instances where standard parametric procedures provide incoherent results. The underlying complexity in the earthquake-magnitude distribution, as well as the number of events in the catalogue (Makran) could explain probably why Andaman and Makran perform better with the non-parametric method.

The zone-characteristic seismic hazard is expressed in terms of mean return periods and the probabilities of being exceeded at least once in a specified time interval for specified earthquake magnitudes. The results, expressed in terms of zone-characteristic hazard curves, showing the probability for a wide range of magnitudes $\left(M_{W}\right)$ to be exceeded in $1,5,10$, and 25 years, are presented in Table 3.

Table 3. The estimated zone-characteristic seismic hazard parameters for the four identified tsunamigenic zones of Makran, South Sandwich Islands (SSI), Sumatra Island, and the Andaman subduction zones.

\begin{tabular}{|l|l|c|l|l|}
\hline & \multicolumn{1}{|c|}{ Makran } & SSI & Sumatra Island & Andaman \\
\hline $\begin{array}{l}\text { Method of Maximum Magnitude } \\
\text { Estimation }\end{array}$ & N-P-G & K-S-B & K-S-B & N-P-G \\
\hline Maximum Magnitude $\left(\widehat{m}_{\max }\right)$ & $8.4 \pm 0.5$ & $8.2 \pm 0.3$ & $9.2 \pm 0.3$ & $9.4 \pm 0.4$ \\
\hline Minimum Magnitude $\left(\widehat{m}_{\min }\right)$ & 4.40 & 5.50 & 5.50 & 5.50 \\
\hline
\end{tabular}




\begin{tabular}{|l|c|c|c|c|}
\hline Gutenberg-Richter $b$-value & $1.01 \pm 0.08$ & $1.00 \pm 0.06$ & $1.00 \pm 0.05$ & $1.07 \pm 0.06$ \\
\hline $\begin{array}{l}\text { Mean Seismic Activity Rate }(\lambda) \\
\text { [earthquakes per year] }\end{array}$ & $0.6 \pm 0.2$ & $6.5 \pm 1.6$ & $5.2 \pm 1.0$ & $4.7 \pm 1.0$ \\
\hline
\end{tabular}

${ }^{1}$ Non-parametric Gaussian maximum magnitude estimation (Kijko and Singh, 2011)

${ }^{2}$ Kijko-Sellevoll-Bayes maximum magnitude estimation (Kijko and Singh, 2011)

The range of estimated earthquake maximum magnitudes $\left(M_{w}\right)$ is [7.9, 8.9] for Makran, [7.9, 8.5] for the South Sandwich Islands, [8.9, 9.5] for Sumatra Island, and [9.0, 9.8] for the Andaman subduction zone. Table 4 provides the respective estimates of the return periods for earthquakes with magnitudes 7.0, 7.5, and 8.0. The most frequent (lowest return period) threat is posed by Sumatra Island, the South Sandwich Islands, and the Andaman subduction zones.

Table 4. The estimated zone-specified seismic hazard parameters for the four identified tsunamigenic zones of Makran, South Sandwich Islands (SSI), Sumatra Island, and the Andaman subduction zones.

\begin{tabular}{|c|c|c|c|c|}
\hline Magnitude & \multicolumn{4}{|c|}{ Return Period (years) } \\
\hline Tsunamigenic zone & Makran & SSI & Sumatra & Andaman \\
\hline 7.0 & 318 & 4 & 5 & 6 \\
\hline 7.5 & 862 & 13 & 11 & 46 \\
\hline 8.0 & 3170 & 90 & 30 & 43 \\
\hline
\end{tabular}

Figure 2 and Table 4 illustrates the return period for a given moment magnitude $\left(M_{w}\right)$ for Makran, South Sandwich Islands, Sumatra Island, and the Andaman subduction zone, respectively. As an example, the return period of earthquake occurrence with magnitude equal to or greater than 7.0 to occur in the Makran subduction zone is approximately every 318 years, every 4 years for South Sandwich Island and every 5 and 6 years respectively for Sumatra Island, and the Andaman subduction zone.. The confidence intervals for the probability of exceedance and return periods ( \pm one standard deviation) are shown in Figure 2.

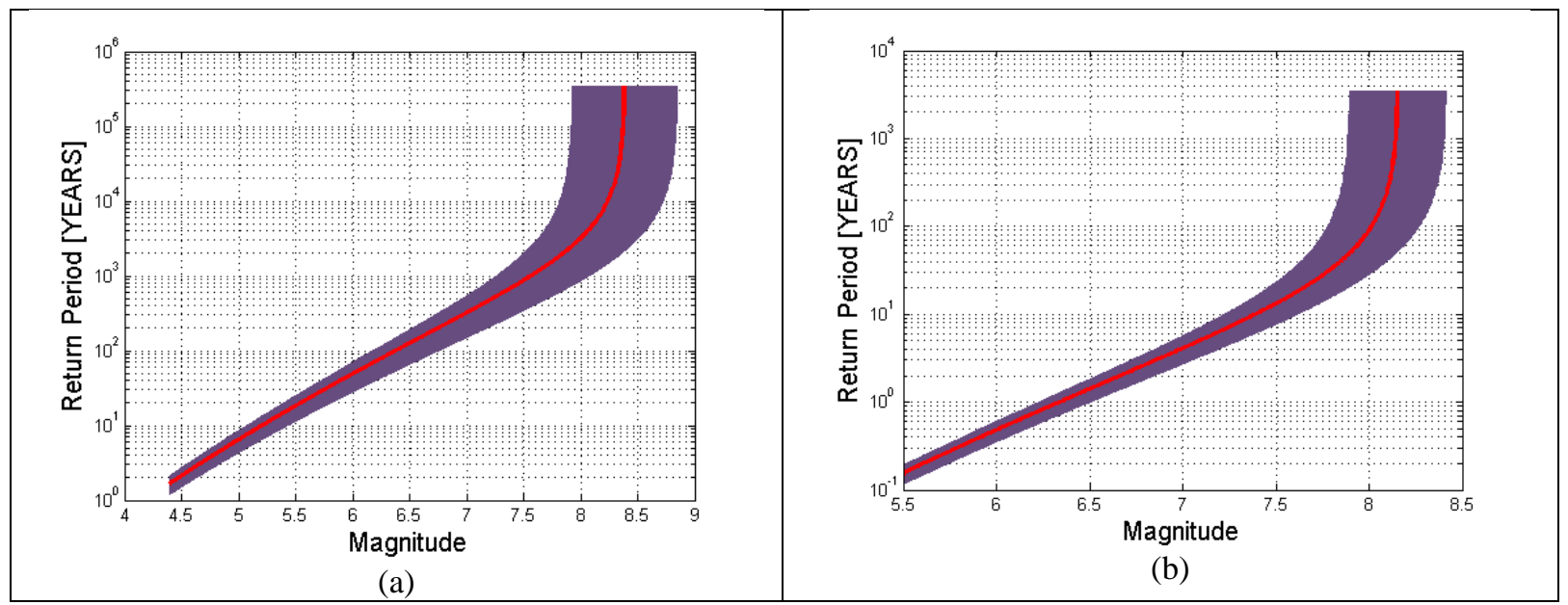




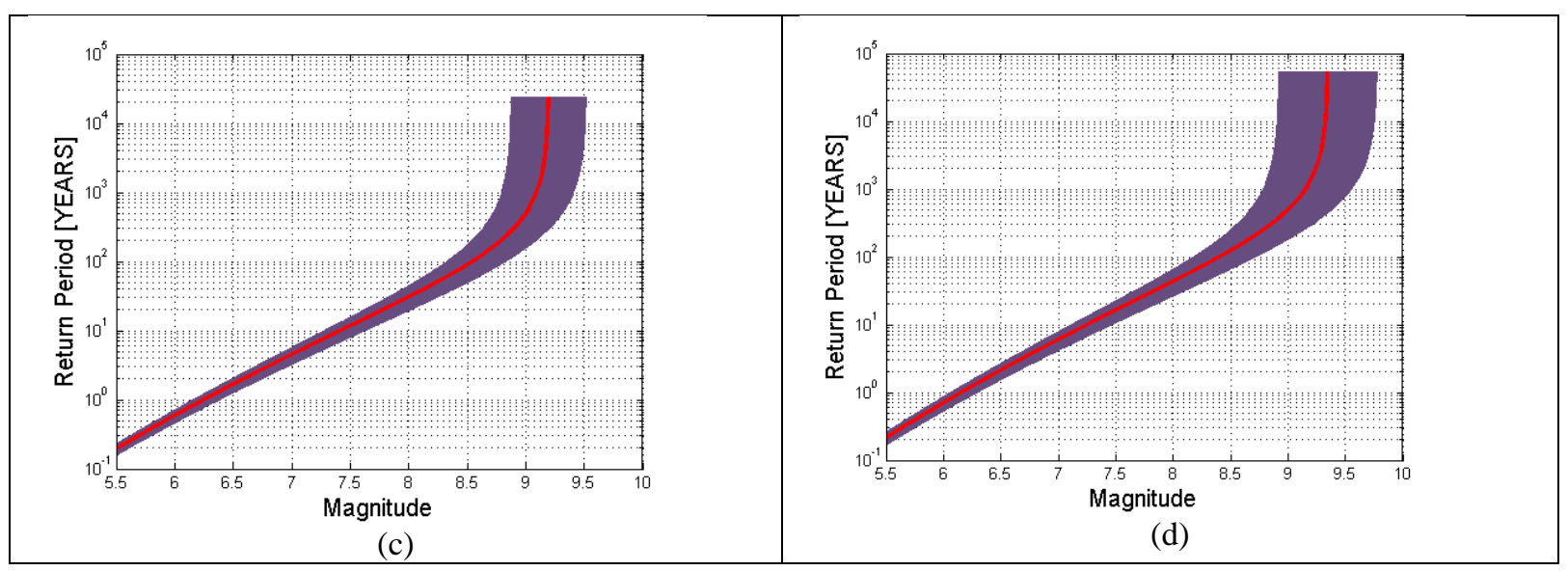

Figure 2: The mean return periods for earthquake magnitude for the subduction zones of a) Makran, b) the South Sandwich Islands, c) Sumatra Island and d) the Andaman subduction zone. The red curve shows the mean return period, whereas the two blue curves indicate the mean return period \pm one standard deviation.

Comparing the above results with those of similar investigations confirms the results of the other researchers to a considerable extent. The report by Berryman et al. (2013), under the auspices of the Faulted Earth Global Component for the Global Earthquake Model (GEM) project, provides extensive and in-depth analysis of parameters impacting the tsunami potential of an area. This report identifies ranges (minimum, maximum, and average) for the Gutenberg-Richer $b$-value and the maximum magnitude for worldwide subduction zones. Determining the maximum earthquake magnitude is based on the rupture length of the different fault segments, as described by McCaffrey (2008). The maximum magnitude estimated for Makran, South Sandwich Islands, Sumatra, and Andaman do not differ significantly from the results obtained by Berryman et al. (2013). As regards to the Makran subduction zone, the estimated $m_{\max }$ was lower than the $M_{w} 8.7$ suggested by Berryman et al. (2013) and Zaman et al. (2012). Moreover, these two studies provide a $b$-value that is much lower and appears to deviate from what is normally observed in areas with tectonic origin seismicity. Therefore, it is prudent to assume that the four identified subduction zones could generate mega-transoceanic tsunamis that could potentially affect the South African coastline and, by implication, the eastern part of the African coastline.

\section{Tsunami Hazard Assessment}

Maximum tsunami wave amplitudes for realistic and worst-case scenarios were estimated by employing numerical techniques (described below) for the three selected sites along the South African coast, namely, the metropolitan cities of Durban, Port Elizabeth, and Cape Town. During the numerical tests, the Sumatra and Andaman zones were combined and analysed as one zone.

The parameters used in the regional modelling of tsunami amplitudes are summarized in Table 5. The values were obtained from Ioualalen et al. (2006), Okal and Synolakis (2008), and Okal and Hartnady (2009), as well as from a number of hypothetical tests for the worst-case scenarios. The geographic longitudes and latitudes of the three hypothetical tide gauges are $31.044^{\circ} \mathrm{E}$ and $29.858^{\circ} \mathrm{S}$ for Durban, $25.604^{\circ} \mathrm{E}$ and $33.948^{\circ} \mathrm{S}$ for Port Elizabeth, and $18.411^{\circ} \mathrm{E}$ and $33.895^{\circ} \mathrm{S}$ for Cape Town.

Numerical simulations for all the scenarios were performed using the GEOWAVE application (Watts et al., 2003), which is a combination of TOPICS (Tsunami Open and Progressive Initial Conditions System) and FUNWAVE. TOPICS uses a variety of curve fitting techniques and was designed (Grilli and Watts, 1999) as a simulation tool to provide approximate surface water elevations and velocities as initial conditions for the tsunami propagation model. The FUNWAVE (Wei and Kirby, 1995; Wei et al., 1995) numerical model performs wave propagation simulation based on the fully non-linear Boussinesq theory, allowing the user to obtain accurate run-up and inundation data at the same time. The use of GEOWAVE for tsunami simulations has been validated well by previous case studies of tsunamis generated by earthquakes (Day et al., 2005; Grilli et al., 2007; Ioualalen et al., 2006, 2007), pyroclastic flows (Watts and Waythomas, 2003; Novikova et al., 
2011), underwater landslides (Watts et al., 2003; Day et al., 2005; Greene et al., 2005), and debris flow (Walder et al., 2003).

The earthquake tsunami source is described by the standard half-plane solution for an elastic dislocation with maximum slip $\Delta$ (Okada, 1985). Accordingly, a planar fault is defined through horizontal length $L$ and width $W$, with the centroid being located at the earthquake epicentre $\left(x_{0}, y_{0}\right)$, and depth $d$. The Okada (1985) solution is implemented in the TOPICS software application. Both homogeneous and heterogeneous (certain number of subfaults with different dimensions and values of slips along the respective faults) were considered in our study. However, it was found that the resulting wave amplitudes at the three sites practically do not differ if applied to the homogeneous or heterogeneous slip models.

The definition of the grid is based mainly on 2 (minute) resolution bathymetry, and topography (ETOPO $2^{\prime}$ database, National Geophysical Data Center, NOAA, USA). This grid covers the region from $60^{\circ} \mathrm{S}$ to $25^{\circ} \mathrm{N}$ and from $28^{\circ} \mathrm{W}$ to $120^{\circ} \mathrm{E}$. The simulation time step was established based on the size of the constructed grid. The maximum tsunami wave amplitudes for realistic (RC) and hypothetical worst-case (WC) scenarios were calculated numerically for each of the three identified sites on the South African coast. The focal parameters used during the simulations are provided in Table 5.

Table 5. Focal parameters of the earthquakes that were applied for tsunami hazard assessment based on the realistic and worst-case scenarios ( $\mathrm{RC}=$ realistic-case and $\mathrm{WC}=$ worst-case) for the subduction zones of Makran, South Sandwich Islands and Sumatra-Andaman.

\begin{tabular}{|c|c|c|c|c|c|c|c|}
\hline Fault & \multicolumn{2}{|c|}{ Makran } & \multicolumn{3}{|c|}{ SSI } & \multicolumn{2}{|c|}{ Sumatra-Andaman } \\
\hline \multirow[t]{2}{*}{ Coordinates } & \multicolumn{2}{|c|}{$\begin{array}{c}{\left[24.38^{\circ} \mathrm{N} ; 57.06^{\circ} \mathrm{E}\right] \text { to }} \\
{\left[26.05^{\circ} \mathrm{N} ; 65.03^{\circ} \mathrm{E}\right]}\end{array}$} & \multicolumn{3}{|c|}{$\begin{array}{c}{\left[40^{\circ} \mathrm{S} ; 63^{\circ} \mathrm{W}\right] \text { to }} \\
{\left[10^{\circ} \mathrm{S} ; 55^{\circ} \mathrm{W}\right]}\end{array}$} & \multicolumn{2}{|c|}{$\begin{array}{l}{\left[8.17^{\circ} \mathrm{S} ; 96.20^{\circ} \mathrm{E}\right] \text { to }} \\
{\left[13.72^{\circ} \mathrm{N} ; 104.58^{\circ} \mathrm{E}\right]}\end{array}$} \\
\hline & RC & WC & $\mathbf{R C}$ & WC1 & WC2 & $\mathrm{RC}$ & WC \\
\hline Fault Length $(\mathrm{km})$ & 326 & 326 & 191 & 191 & 191 & 943 & 550 \\
\hline Fault Width (km) & 105 & 105 & 78 & 78 & 78 & 191 & 175 \\
\hline $\begin{array}{l}\text { Mean Displacement } \\
\text { (m) }\end{array}$ & 4.92 & 4.92 & 2.62 & 2.62 & 2.62 & 16.97 & 13 \\
\hline Strike (degree) & 236 & 280 & 38 & 272 & 130 & 338 & 280 \\
\hline $\begin{array}{l}\text { Hypocenter depth } \\
(\mathrm{km})\end{array}$ & 27 & 27 & 35 & 15 & 35 & 25 & 25 \\
\hline $\begin{array}{l}\text { Coordinates of } \\
\text { hypocenter (deg.) }\end{array}$ & $\begin{array}{c}24.61^{\circ} \mathrm{N} ; \\
60.1^{\circ} \mathrm{E}\end{array}$ & $\begin{array}{l}25.0^{\circ} \mathrm{N} ; \\
62.3^{\circ} \mathrm{E}\end{array}$ & $\begin{array}{l}27.3^{\circ} \mathrm{S} \\
55.5^{\circ} \mathrm{W}\end{array}$ & $\begin{array}{l}27.3^{\circ} \mathrm{S} \\
55.5^{\circ} \mathrm{W}\end{array}$ & $\begin{array}{l}26.9^{\circ} \mathrm{S} \\
58.1^{\circ} \mathrm{W}\end{array}$ & $\begin{array}{l}3.3^{\circ} \mathrm{N} \\
95.8^{\circ} \mathrm{E}\end{array}$ & $\begin{array}{l}8.3^{\circ} \mathrm{N} ; \\
98.0^{\circ} \mathrm{E}\end{array}$ \\
\hline Dip Angle (degree) & $7(2-27)$ & 7 & 50 & 57 & 50 & $8(8-15)$ & 7 \\
\hline Slip Rake (degree) & 90 & 90 & 95 & 71 & 95 & 90 & 90 \\
\hline Magnitude $\left(\mathrm{M}_{\mathrm{w}}\right)$ & 7.5 & 8.2 & 7.5 & 8.13 & 8.3 & 9.1 & 8.9 \\
\hline
\end{tabular}

\subsection{Realistic scenarios}

The predicted tsunami amplitudes for the realistic scenarios at the three South African coastal sites are extremely small (Table 6). In fact, the largest amplitudes, being in the order of a few centimetres (Figure A1-1, Appendix), were expected to be generated by an earthquake that occurred at the Sumatra-Andaman tsunamigenic zone. Even lower amplitudes were obtained from the Makran (Figure A2, Appendix) and South Sandwich Islands (Figure A3, Appendix) sources. The parameters of these seismic sources are given in Table 5. The results indicate clearly that the tsunami hazard related to the three distant seismic sources is minimal.

To investigate more complex and, perhaps, more realistic scenarios, we also employed the model for heterogeneous slip distribution to the seismic faults. The model for heterogeneous slip did not change the resulting far-field tsunami wave amplitudes. In fact, the calculated amplitudes for all three locations had the same values as those obtained from a model with homogeneous seismic slip. However, in the case of the 
Sumatra-Andaman zone, the energy directivity effect, as observed during the 2004 mega-tsunami, was reproduced better by employing the heterogeneous slip model (Figure A1-2, Appendix).

Table 6. Calculated offshore tsunami amplitudes $(\mathrm{m})$ from the realistic and worst-case scenario models with homogeneous and heterogeneous slip for the considered seismic zones ( $\mathrm{RC}=$ realistic-case and $\mathrm{WC}=$ worstcase) for the subduction zones of Makran, South Sandwich Islands and Sumatra-Andaman.

\begin{tabular}{|l|c|c|c|c|c|c|c|}
\hline Site & \multicolumn{9}{|c|}{ Amplitudes (m) } \\
\hline & \multicolumn{1}{|c|}{ Makran } & \multicolumn{3}{c|}{ SSI } & \multicolumn{2}{c|}{ Sumatra-Andaman } \\
\hline & RC & WC & RC & WC1 & WC2 & RC & WC \\
\hline Cape Town & 0.003 & 0.06 & 0.011 & 0.02 & 0.29 & 0.03 & 0.037 \\
\hline Port Elizabeth & 0.006 & 0.07 & 0.037 & 0.05 & 0.06 & 0.04 & 0.078 \\
\hline Durban & 0.009 & 0.13 & 0.001 & 0.008 & 0.11 & 0.06 & 0.21 \\
\hline
\end{tabular}

\subsection{Worst-Case Scenarios}

Running number of scenarios with various source parameters for every seismic zone, we selected the cases when the tsunami influence at the considered coastal zone will be maximum. We considered 'worst case' conditions in terms of source orientation and the direction of wave energy radiation, i.e. in cases where wave energy is directed toward the investigated site and we selected the hypocenter location that would maximize the phenomenon. Final values of those tests were presented in Table 5.

\subsubsection{Sumatra-Andaman Tsunamigenic Zone}

The worst-case hazard scenario for the coasts of Kenya, Tanzania, and South Africa would be a repeat of the 25 November 1833 great earthquake (Figure 3), with the expected impact likely more severe than that of the 26 December 2004 event. Okal and Hartnady (2009) attributed this to the more southerly azimuth of the energy directivity pattern. The parameters for a scenario such as the 1833 earthquake are given in Table 5. Accordingly, in this study, calculations were performed by using the parameters of the 1833 earthquake with homogeneous seismic slip. This scenario is considered a worst-case scenario for a tsunami generated by the Sumatra-Andaman zone.

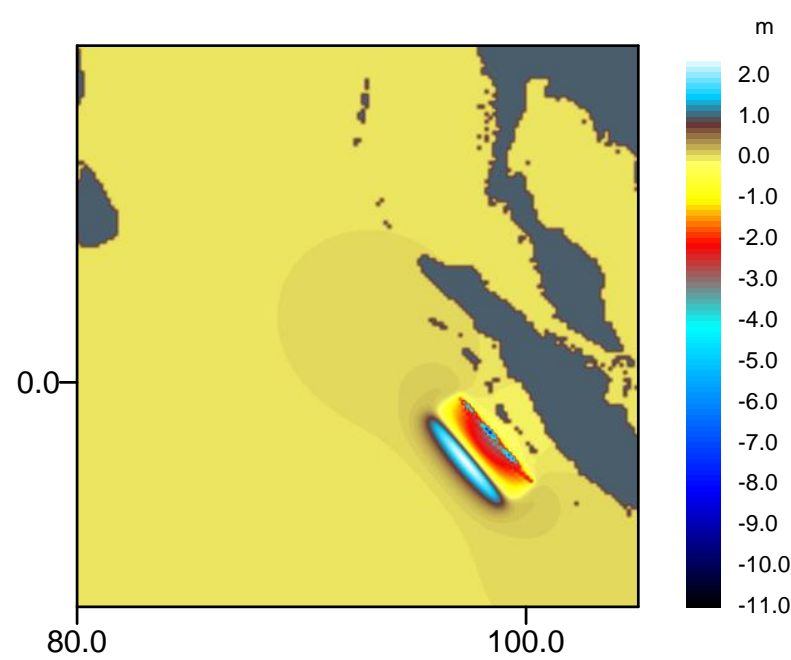

Figure 3. Static fault displacement generated by the 1833 Sumatra earthquake, which is used for modelling the worst-case scenario. 
Based on the 1833 scenario, offshore tsunami amplitudes range between $0.037 \mathrm{~m}$ and $0.21 \mathrm{~m}$ (Table 6). The distribution of the amplitudes is shown in Figure 4, with the initial surface elevation presented in Figure 3. The wave amplitude values were shown to be 1.2 to 3.5 times larger than those produced by the Sumatra 2004 seismic model. The expected impact of such a tsunami would be considerably stronger than that from the 2004 tsunami. This is ascribed principally to the more southerly azimuth of the energy directivity pattern, controlled by the geometry of the earthquake source.

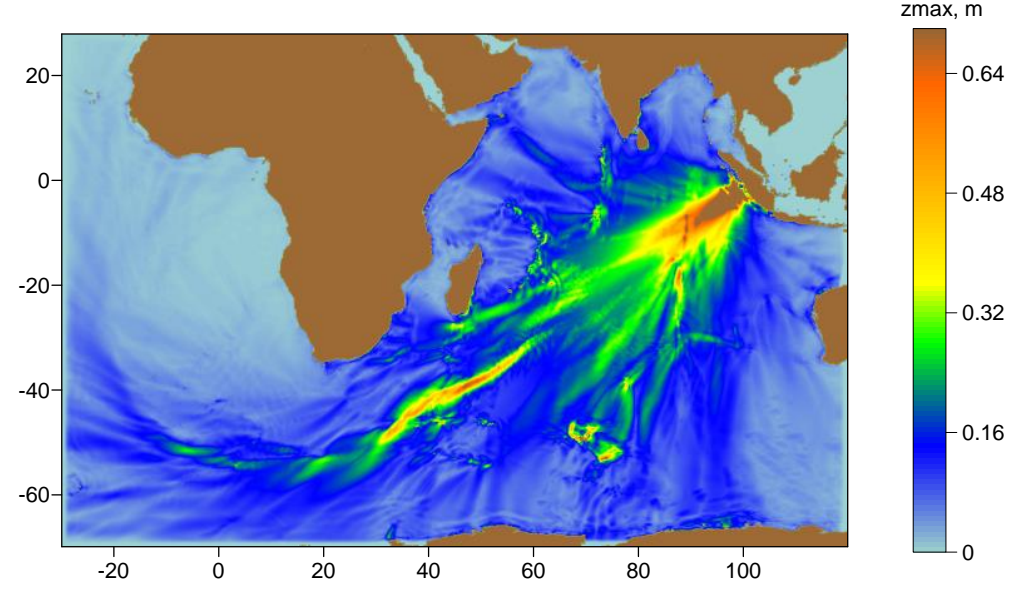

Figure 4. Estimated maximum surface elevation owing to the 1833 Sumatra earthquake with homogeneous seismic slip. The earthquake parameters are given in Table 5. The triangles from east to west represent Durban, Port Elizabeth, and Cape Town.

\subsubsection{Makran Tsunamigenic Zone}

We conducted a simulation of the worst-case tsunami scenario generated by the Makran tsunamigenic zone, assuming the occurrence of an earthquake with a homogeneous slip and focal parameters, as shown in Table 5. The configuration of this subduction zone can be found in Byrne et al. (1992). The corresponding static coseismic fault displacement is illustrated in Figure A4 (Appendix). However, in the selection process for the worst-case scenario, the different directions (strike) of the fault were tested, with the aim to direct (focus) tsunami energy toward the South African coast (Figure A5, Appendix). The final fault strike selected was equal to $280^{\circ}$. The estimated tsunami amplitudes are listed in Table 6 . Although still insignificant, they are slightly larger than those obtained by the realistic scenarios. The tsunami impact to the selected sites in this scenario remains minimal.

\subsubsection{South Sandwich Islands Tsunamigenic Zone}

To assess the worst-case scenario for a tsunami of which the source is off the South-Sandwich Islands (Figure A6, Appendix), we employed the earthquake parameters for homogeneous seismic slip, as provided in Table 5. In addition, a number of tests were performed by varying the hypocentre depth and the strike of the earthquake fault, with the aim to direct maximum tsunami energy toward the South African coast (Figure A7, Appendix). This scenario is referred to as worst-case scenario 1. It was found that by keeping the seismic moment unchanged, the variation of the earthquake fault strike did not affect the tsunami amplitudes obtained at the three selected sites. The amplitudes obtained for an earthquake fault strike of $130^{\circ}$ are listed in Table 6 , and the amplitude distribution is shown in Figure A7 and the Appendix.

A tsunami was simulated for this region in accordance with the study of Okal and Hartnady (2009). The simulation considered a tsunami-generating earthquake with the parameters as shown in Table (of their work). This is an alternative scenario, referred to as worst-case scenario 2 , and assumed that an interplate thrust could generate an earthquake at the southern corner of the arc. According to Okal and Hartnady (2009), this is the most dangerous tsunami scenario for the African and South African coast. The strong effect of tsunami wave 
generated during such event would be the result of source directivity and wave focusing during its propagation. The results of our numerical experiment are similar to those obtained by Okal and Hartnady (2009). Their study indicated wave amplitude equal to $0.3 \mathrm{~m}$ offshore from Cape Town. Our calculations resulted amplitudes of $0.29 \mathrm{~m}$ in Cape Town, $0.06 \mathrm{~m}$ in Port Elizabeth, and $0.11 \mathrm{~m}$ in Durban (Figure 5).

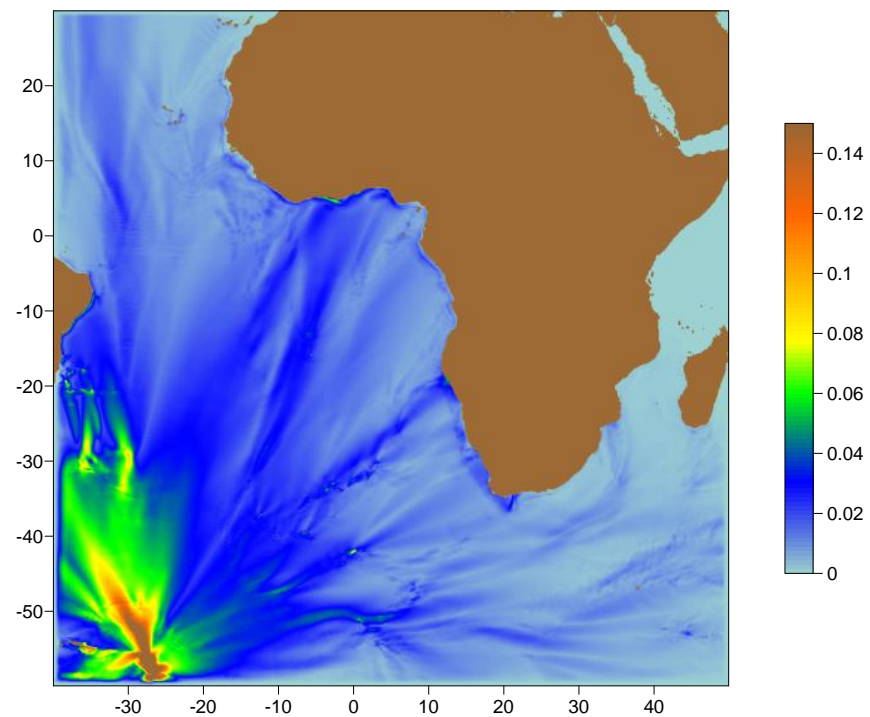

Figure 5. The estimated maximum surface elevation (m) owing to worst-case scenario 2 for the South Sandwich Islands earthquake, with homogeneous seismic slip and fault strike equal to $130^{\circ}$. The earthquake parameters are as given in Table 5. Triangles are as in Figure 4.

The Sumatra-Andaman zone is considered the most dangerous zone, as it can generate earthquakes of magnitude 7.0 and larger for shorter return periods compared with the other three zones. These earthquakes can generate a high amplitude tsunami that could affect the South African coast. In the case of the Makran seismic zone, earthquakes with similar magnitudes have return periods of more than 300 years. For this tsunamigenic region, only the worst-case scenario could be considered a threat to South Africa. A 90-year return period was calculated for the South Sandwich Island subduction zone for an earthquake of magnitude 7.0 or higher. Earthquakes with lower magnitudes that occur more frequently cannot generate a tsunami with a significant amplitude to affect the South African coast negatively.

Table 7.Simulated tsunami run-up (RU) in metres calculated (right columns) for the worst-case scenarios (WC). Values in parentheses for the South Sandwich Islands source represent the run-up values obtained for worst-case scenario 2.

\begin{tabular}{|l|c|c|c|c|}
\hline \multirow{2}{*}{ Site } & Makran & \multicolumn{2}{|c|}{ SSI } & Sumatra-Andaman \\
\cline { 2 - 5 } & WC & WC1 & WC2 & WC \\
\hline Cape Town & 0.83 & RU & RU & RU \\
\hline Port Elizabeth & 0.93 & 0.4 & 2.5 & 0.6 \\
\hline Durban & 1.43 & 0.19 & 0.8 & 1.0 \\
\hline
\end{tabular}

Estimates that are more accurate of tsunami run-up values for the South African coast can be obtained only after the implementation of the local model, with the incorporation of the high-resolution sources of near-shore 
bathymetry and coastal area topography. Such application could increase the offshore wave amplitude and, consequently, could improve the run-ups values.

\section{Conclusions}

Failing to quantify hazards accurately could have devastating effects on the infrastructure of a country, its economic stability, and the quality of life of its people (World Bank, 2005). The general perception is that South Africa is safe from the impact of a mega-transoceanic tsunamis. The intention of this work was to discuss this assumption by combining seismic and tsunami hazard procedures into a unified study and to quantify the tsunami threat to the South Africa coastline. As shown, the Makran, South Sandwich Island, Sumatra, and the Andaman subduction zones could generate mega-earthquakes that could result in transoceanic tsunamis of amplitudes that could have a negative impact on the coastline.

Three factors were identified as major contributors to the uncertainty of the tsunami hazard estimates. First, uncertainty is introduced by the application of relatively short earthquake catalogues. The seismic event dataset of the South Sandwich Islands does not span100 years, and the catalogues for the Makran, Sumatra, and the Andaman subduction zones span 564, 330, and 174 years, respectively. It is quite likely that the full seismic cycle of a mega-earthquake magnitude would be larger than the time spans of each of these catalogues. Since the assessment of zone-characteristic seismic hazard parameters did not include prehistoric-earthquake information, the results are uncertain and potentially could underestimate the zone-characteristic, maximum possible earthquake magnitudes and, at the same time, overestimate the return periods. Future research is required, where the available information should be utilised by applying the Bayesian formalism.

The second form of data uncertainty is that only a small fraction of large earthquakes in subduction zones generate mega-tsunamis. The probability of a significant earthquake occurrence induced by the Makran subduction zone during the next 25 years is extremely small. Additional investigation is required to determine a realistic value of the fraction of earthquakes capable of generating mega-tsunamis, and in what way this would affect the relevant seismic hazard recurrence parameters.

The third factor of uncertainty is the inclusion of local tsunamigenic sources in the calculations. Only distant tsunamigenic sources were considered owing to the size and inferior quality of historical records on local tsunamis. As pointed out in a report by ESKOM (2009), a tsunami generated by an offshore landslide is considered the largest unknown risk factor for the South African coast. There is increasing recognition of the role that submarine and coastal landslides could play in the generation of powerful tsunamis. Accordingly, future research should incorporate such tsunami sources, using, for example, the information provided by Roberts (2008) and Luger (2010) on the evidence for South African submarine slumps.

Several conclusions can be drawn from the results of the numerical tsunami simulation for the regional model. The simulated realistic scenarios of tsunami hazard for Durban, Port Elizabeth, and Cape Town by the three analysed subduction zones showed relatively small tsunami amplitudes, which do not represent a significant risk to the South African coast. This is also true for the worst-case scenarios, with the estimated wave amplitudes not being changed significantly; however, the worst-case scenarios better represent the observed effect of energy directivity.

Our results are consistent to a large extent with the outcomes of similar investigations performed by other researchers, who applied different simulation techniques. By incorporating additional sources of information into the local model, such as high-resolution near-shore bathymetry and the coastal topography of each selected site, assessments that are more accurate could be obtained. It is expected that after incorporating the local models, the run-up in the three analysed coastal sites could reach $2 \mathrm{~m}$, which is a considerable height from a tsunami risk perspective.

The results of the tsunami hazard assessment for the coast of South Africa indicate that the tsunami threat appears to be important subject for further detailed study including also a-seismic sources and employing finer bathymetric sources for propagation model.. These results and the factor of data uncertainty suggest that additional research and superior quality data are required to increase the accuracy of the tsunami hazard assessment. Therefore, the results provided in this article should be treated as preliminary only. 


\section{Acknowledgements}

The project was financially supported by both the Nuclear Structural Engineering (Pty) and the National Research Foundation through the Technology and Human Resources for Industry Programme project (THRIP) TP2011061400009. The authors would like to extend their gratitude to Professor H. Gupta for valuable insights into the possible seismogenic sources that could have an effect on South Africa.

\section{References}

Ben-Avraham, Z., Smith, G., Reshef, M., and Jungslager, E. (2002). Gas hydrate and mud volcanoes on the southwest African continental margin off South Africa. Geology, 30(10), 927-930.

Benjamin, J.R. 1968. Probabilistic models for seismic forces design, J. Struct. Div. ASCE. 94, (ST5) 1175-1196.

Berryman, K., Wallace, L., Hayes, G., Bird, P., Wang, K., Basili, R., Lay, T., Stein, R., Sagiya, T., Rubin, C., Barreintos, S., Kreemer, C., Litchfield, N., Pagani, M., Gledhill, K., Haller, K., and Costa, C. 2013. The GEM Faulted Earth Subduction Characterisation Project. Report produced in the context of the GEM Faulted Earth Global Components.

Brizuela, B., Armigliato, A., and Tinti, S. 2014. Assessment of tsunami hazards for the Central American Pacific coast from southern Mexico to northern Peru. Nat. Hazards Earth Syst. Sci., (14), 1889-1903.

Burbidge, D.R., Cummins, P.R., Latief, H., Mleczko, R., Mokhtari, M., Natawidjaja, D., Rajendran, C.P., and Thomas, C. 2009. A Probabilistic Tsunami Hazard Assessment of the Indian Ocean Nations. Australian Government, Geoscience Australia, Professional Opinion, No. 2009/11.

Byrne, D. E., Sykes, L., and D. Davis, (1992). Great thrust earthquakes and aseismic slip along the plate boundary of the Makran subduction zone, J. Geophys. Res., 97, pp., 449-478.

Campbell, K.W. 1982. Bayesian analysis of extreme earthquake occurrences. Part I. Probabilistic hazard model. Bull. Seismol. Soc. Am. 72, 1689-1705.

Campbell, K.W. 1983. Bayesian analysis of extreme earthquake occurrences. Part II. Application to the San Jacinto fault zone of southern California. Bull. Seismol. Soc. Am. 73, 1099-1115.

Choi, B.H., Pelinovsky, E., Kim, K.O. and Lee, J.S., (2003). Simulation of the trans-oceanic tsunami propagation due to the 1883 Krakatau volcanic eruption. Natural Hazards and Earth System Sciences, 3(5), pp.321-332.

Cornell, C.A. 1968 Engineering seismic risk analysis, Bull. Seismo. Soc. Am., 58, 1,583-1,606.

Cornell, C.A. 1971. Probabilistic analysis of damage to structures under seismic loads, in Howells, D.A, Haigh, I.P., and Taylor, C., eds., Dynamic waves in civil engineering: Proceedings of a conference organized by the Society for Earthquake and Civil Engineering Dynamics, New York, John Wiley, 473-493.

Day, S.J., Watts, P., Grilli, S.T., Kirby, J.T. 2005. Mechanical models of the 1975 Kalapana, Hawaii earthquake and tsunami. Mar. Geol. 215, 59-92.

Dingle, R.V. (1980). Large allochthonous sediment masses and their role in the construction of the continental slope and rise off south western Africa. Mar. Geol., 37, 333-354.

Dingle, R.V., Birch, G.F., Bremner, J.M., De Decker, R.H., Du Plessis, A., Engelbrecht, J.C., Fincham, M.J., Fitton, T., Flemming, B.W., Gentle, R.I., Goodlad, S.W., Martin, A.K., Mills, E.G., Moir, G.J., Parker, R.J., Robson, S.H., Rogers, J., Salmon, D.A., Siesser, W.G., Simpson, E.S.W.. Summerhayes, C.P., Westall, C.F., and Winter A. 1987. Deep-sea sedimentary environments around southern Africa, SouthEast Atlantic and South-West Indian Oceans. Ann. S. Afr. Mus., 98, 1-27. 
Dingle, R.V., and Robson, S.H. 1992. South western Africa continental rise: Structural and sedimentary evolution. In: C.W. Poag, and P.C. Graciansky (eds.), Geologic Evolution of Atlantic Continental Rises. New York, Van Nostrand, 62-76.

ESKOM (2009). ESKOM Nuclear Sites Site Safety Reports. Numerical Modelling of Coastal Processes. Duynefontein. Report No. 1010/4/101. September 2009. pp. 17.

González, F.I., Geist, E.L., Jaffe, B., Kânoğlu, U., Mofjeld, H., Synolakis, C.E., Titov, V.V., Arcas, D., Bellomo, D., Carlton, D. and Horning, T., 2009. Probabilistic tsunami hazard assessment at seaside, Oregon, for near-and far-field seismic sources. Journal of Geophysical Research: Oceans, 114, C11.

Greene, H.G., Murai, L.Y., Watts, P., Maher, N.A., Fisher, M.A., Paull, C.E., Eichhubl, P. (2005). Submarine landslides in the Santa Barbara Channel as potential tsunami sources. Nat Hazards Earth System Sci. 6, 63-88.

Grilli, S.T., and Watts, P. (1999). Modelling of waves generated by a moving submerged body: Applications to underwater landslides. Engrg. Analysis with Boundary Elements. 23(8), 645-656.

Grilli, S.T., Ioualalen, M., Asavanant, J., Shi, F., Kirby, J.T., Watts, P. (2007). Source constraints and model simulation of the December 26, 2004 Indian Ocean tsunami. J. Waterw. Port Coastal Ocean Eng. 133(6), 414-428.

Hartnady, C.J.H., and Botha, J. (2007). Earthquake risk assessment for the Western Cape. Department of Local Government and Housing, Western Cape Provincial Government.

Ioualalen, M., Pelletier, B., Regnier, M., Watts, P. (2006). Numerical modelling of the 26th November 1999 Vanuatu tsunami. J. Geophys. Res. 1111, C06030, doi: 10.1029/2005JC003249.

Ioualalen, M., Asavanant, J., Shi, F., Kirby, J.T., Watts, P. (2007). Modeling the 26 December 2004 Indian Ocean tsunami: Case study of impact in Thailand. J. Geophys.Res. 112, C07024, doi: 10.1029/2006JC003850.

Joseph, A., Odametey, J.T., Nkebi, E.K., Pereira, A., Prabhudesai, R.G., Mehra, P., Rabinovich, A.B., Kumar,V., Prabhu-Desai, S., and Woodworth, P. (2006). The 26 December 2004 Sumatra tsunami recorded on the coast of West Africa. African Journal of Marine Science, 28(3-4), pp.705-712.

Karimiparidari, S., Zaré, M., Memarian, H., and Kijko, A. (2013). Iranian earthquakes, a uniform catalog with moment magnitudes. Journal of Seismology, 17(3), pp.897-911.

Kijko, A. (2004). Estimation of the maximum earthquake magnitude mmax. Pure Appl. Geophys, 161, 1-27.

Kijko, A., and Singh, M. (2011). Statistical tools for maximum possible earthquake magnitude estimation. Acta Geophysica. 59, 674-700.

Kijko, A., Smit, A., and Sellevoll, M.A. (2016). Estimation of earthquake hazard parameters from incomplete data files, Part III, Incorporation of Uncertainty of Earthquake-Occurrence Model. Bull. Seismol. Soc. Am, pp.13.

Luger, S.A. (2010). Eskom Nuclear Sites Site Safety Reports: Numerical modelling of coastal processes Thyspunt. Prestedge Retief Dresner Wijnberg (Pty) Ltd Report 1010/2/102, 173 pp.

McCaffrey, R. (2008), Global frequency of magnitude 9 earthquakes. Geol., 36(3), p. 263-266.

Novikova, T., Papadopoulos, G.A., McCoy, F.W. (2011). Modelling of Tsunami Generated by the Giant Late Bronze Age Eruption of Thera, South Aegean Sea, Greece. Geoph. J. Int. 186, 665-680 doi: 10.1111/j.1365-246X.2011.05062.

Okada, Y. (1985). Surface deformation due to shear and tensile faults in a half-space. Bull. Seismol. Soc. Amer. 75, 1135-1154. 
Okal, E.A. and Hartnady, C.J. (2009). The South Sandwich Islands earthquake of 27 June 1929: Seismological study and inference on tsunami risk for the South Atlantic. South African Journal of Geology, 112(34), pp.359-370.

Okal, E.A., and Synolakis, C.E. (2008). Far-field tsunami hazard from mega-thrust earthquakes in the Indian Ocean. Geophys, J, Int, 172(3), 995-1015.

Pacheco, J. F., Lynn R. Sykes, and Ch.H.Scholz, (1993). Nature of seismic coupling along simple plate boundaries of the subduction type, Journal of Geophysical Research 98, no. B8:14133-14159

Power, W., Downes, G., and Stirling, M. (2007). Estimation of tsunami hazard in New Zealand due to South American earthquakes. Pure Appl. Geophys., 164, 547-564, doi:10.1007/s00024-006-0166-3.

Roberts, D. L. (2008). Nuclear siting investigation programme: Potential sources of tsunami along the South African coast. Council for Geoscience 2008-0220,35pp.

Ruff L. J. and H.Kanamori, (1980). Seismicity and the subduction process," Physics of the Earth and Planetary

Interiors 23:240-252.

Salzmann, L., and Green, A. (2012). Boulder emplacement on a tectonically stable, wave-dominated coastline, Mission Rocks, northern KwaZulu-Natal, South Africa. Marine Geology, 323; 95-106

Sørensen, M. B., Spada, M., Babeyko, A., Wiemer, S., and Grünthal, G. (2012). Probabilistic tsunami hazard in the Mediterranean Sea, J J. Geophys.Res, , 117, doi: 10.1029/2010JB008169

Storchak, D.A., Di Giacomo, D., Bondár, I., Engdahl, E.R., Harris, J., Lee, W.H.K., Villaseñor, A., and Bormann, P. (2013). Public Release of the ISC-GEM Global Instrumental Earthquake Catalogue (1900-2009). Seism. Res. Lett., 84(5), 810-815, doi: 10.1785/0220130034.

Thomalla, F., Larsen, R. K. (2010). Resilience in the context of tsunami early warning systems and community disaster preparedness in the Indian Ocean region. Environmental Hazards, 9(3), 249-265.

Walder, J., Watts, P., Sørensen, O., Janssen, K. (2003). Tsunamis generated by subaerial mass flows. J. Geophys. Res. 108, NB5, 1-19.

Ward, S.N., Day, S. (2008). Tsunami balls: A granular approach to tsunami runup and inundation. Communications in computational physics. 3, N1, 222-249.

Watts, P., Waythomas, C.F. (2003). Theoretical analysis of tsunami generation by pyroclastic flows. J. Geophys. Res. 108, B12, 1-19.

Watts, P., Grilli, S.T., Kirby, J.T., Fryer, G.J., Tappin, D.R. (2003). Landslide tsunami case studies using a Boussinesq model and a fully nonlinear tsunami generation model. Nat. Hazards and Earth Syst. Sci. 3(5), 391-402.

Wefer, G., Berger, W.H., Richter, C., et al. (1998). Shipboard Scientific Party, 1998, Site 1086 In G. Wefer, W.H. Berger, C. Richter et al., Proceedings of the Ocean Drilling Program, Initial Reports, Vol. 175, College Station, TX (Ocean Drilling Program), p. 429. doi:10.2973/odp.proc.ir.175.1998

Wei, G., Kirby, J.T. (1995). Time-depended numerical code for extended Boussinesq equations. J. Wtrwy, Port, Coast, and Oc. Engrg. ASCE, 121 (5), 251-261.

Wei, G., Kirby, J.T., Grilli, S.T., Subramanya, R. (1995). A fully nonlinear Boussinesq model for free surface waves. Part 1: Highly nonlinear unsteady waves. J. Fluid Mech. 294, 71-92.

Word Bank (2005). World Bank East Asia and Pacific Economic Update 2011, Vol. 1; World Bank Response to the Tsunami Disaster, February 2, 2005.

Zaman S., Ornthammarath, T., Warnitchai, P. (2012). Probabilistic Seismic Hazard Maps for Pakistan. 15 WCEE Lisbon 2012. 


\section{Appendix}

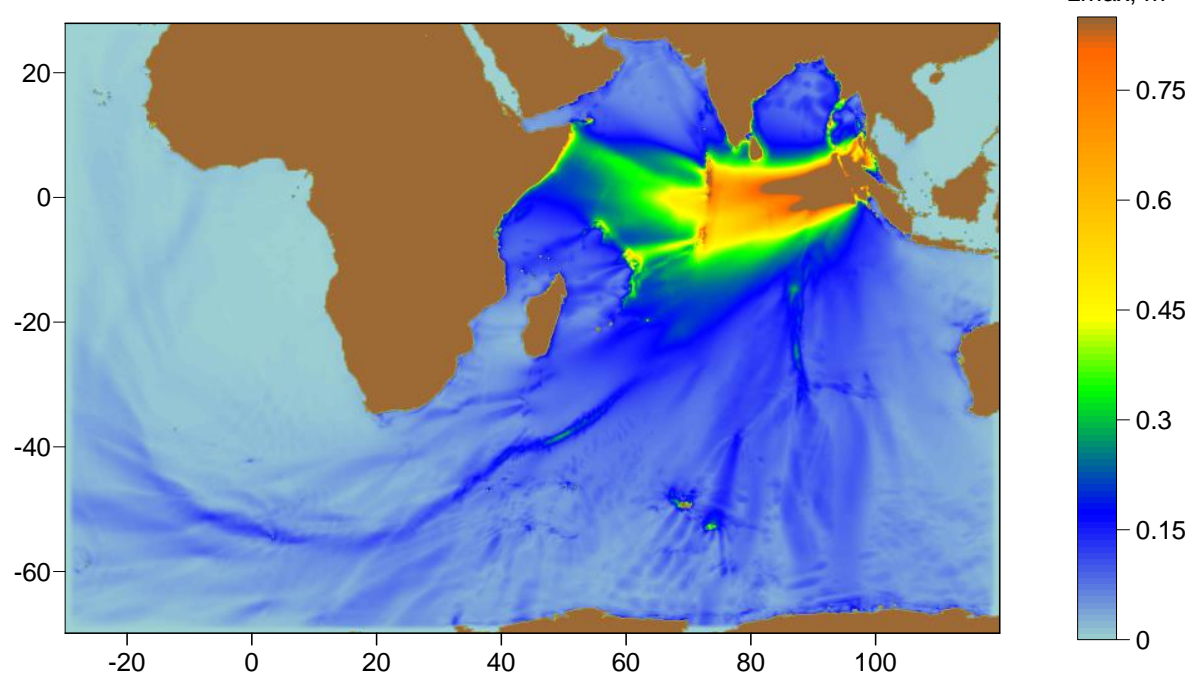

Figure A1-1. Maximum surface elevation (m) at all times after an earthquake with homogeneous seismic slip generated in the Sumatra-Andaman zone. The earthquake parameters are listed in Table 5. Triangles from east to west represent Durban, Port Elizabeth, and Cape Town.

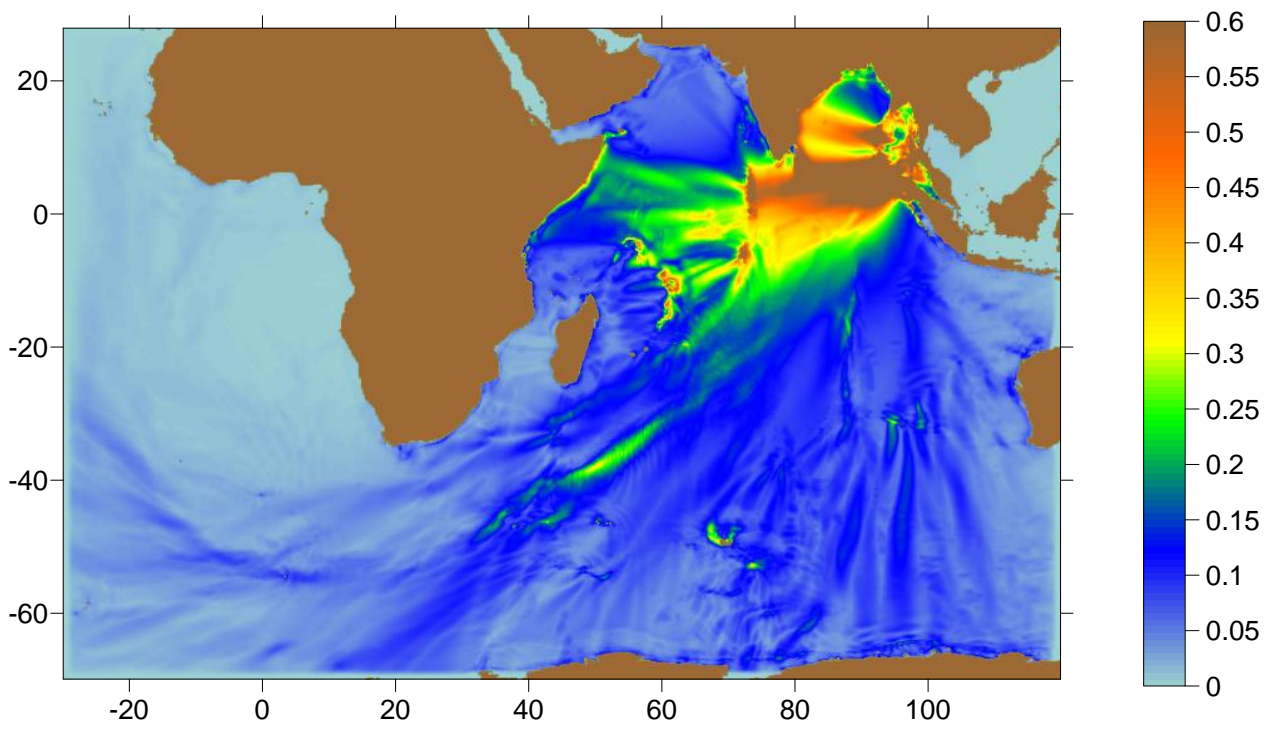

FigureA1-2. Maximum surface elevation (m) at all times after an earthquake with heterogeneous seismic slip at the Sumatra-Andaman tsunamigenic zone. Earthquake parameters are listed in Table 5. Triangles are as in Figure S1. 


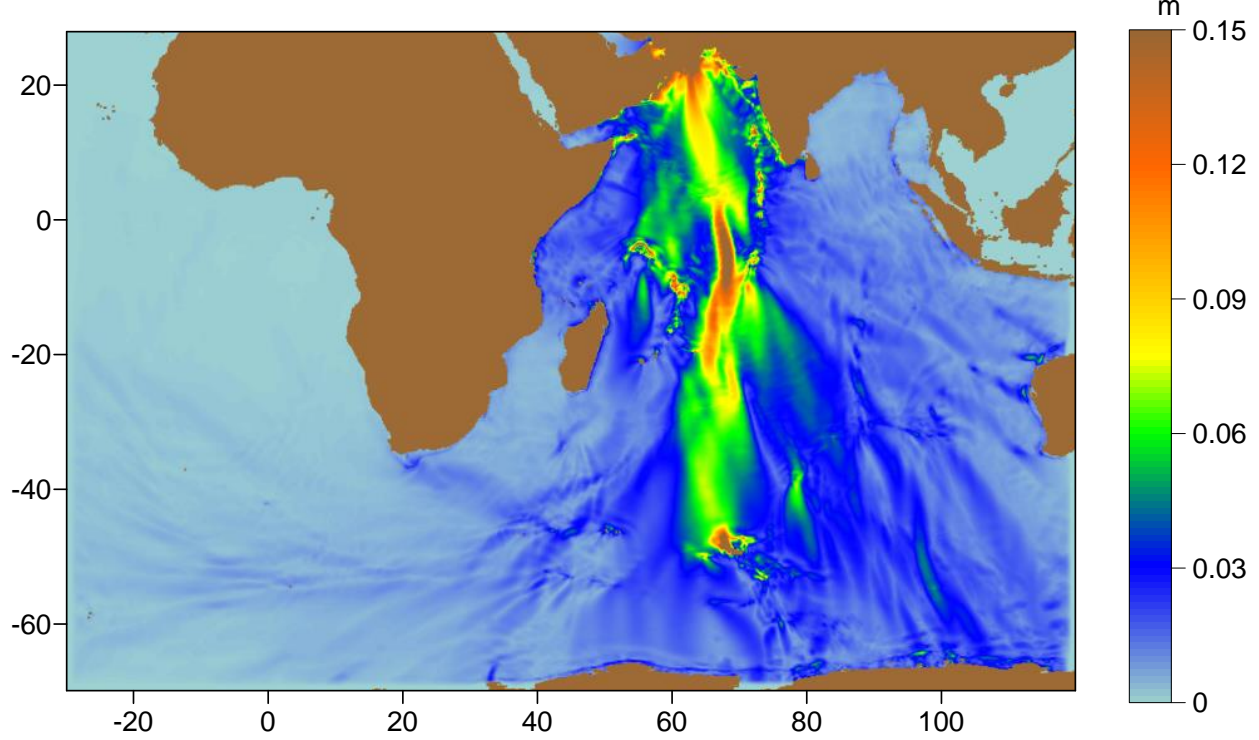

Figure A2. Maximum surface elevation (m) at all times after an earthquake with homogeneous slip generated in the Makran tsunamigenic zone. The earthquake parameters are listed in Table 5. Triangles are as in Figure A1-1.

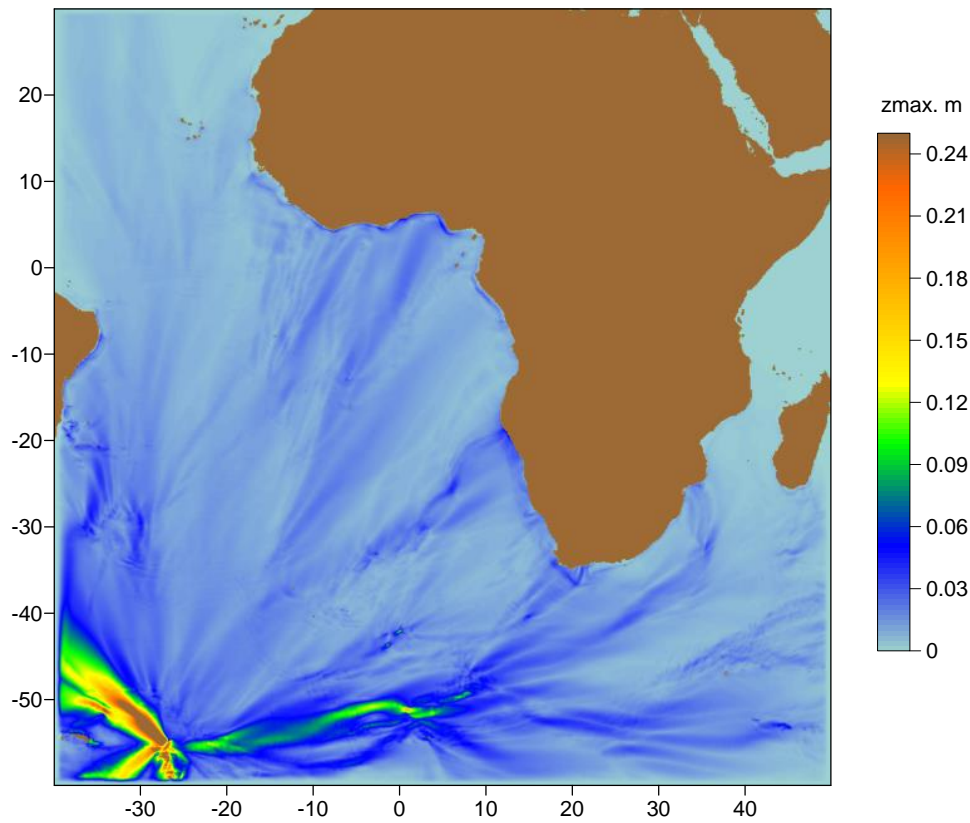

Figure A3. Maximum surface elevation (m) at all times owing to homogeneous seismic slip produced by an earthquake at the South Sandwich Islands zone. The earthquake parameters are listed in Table 5. Triangles are as in Figure A1-1. 


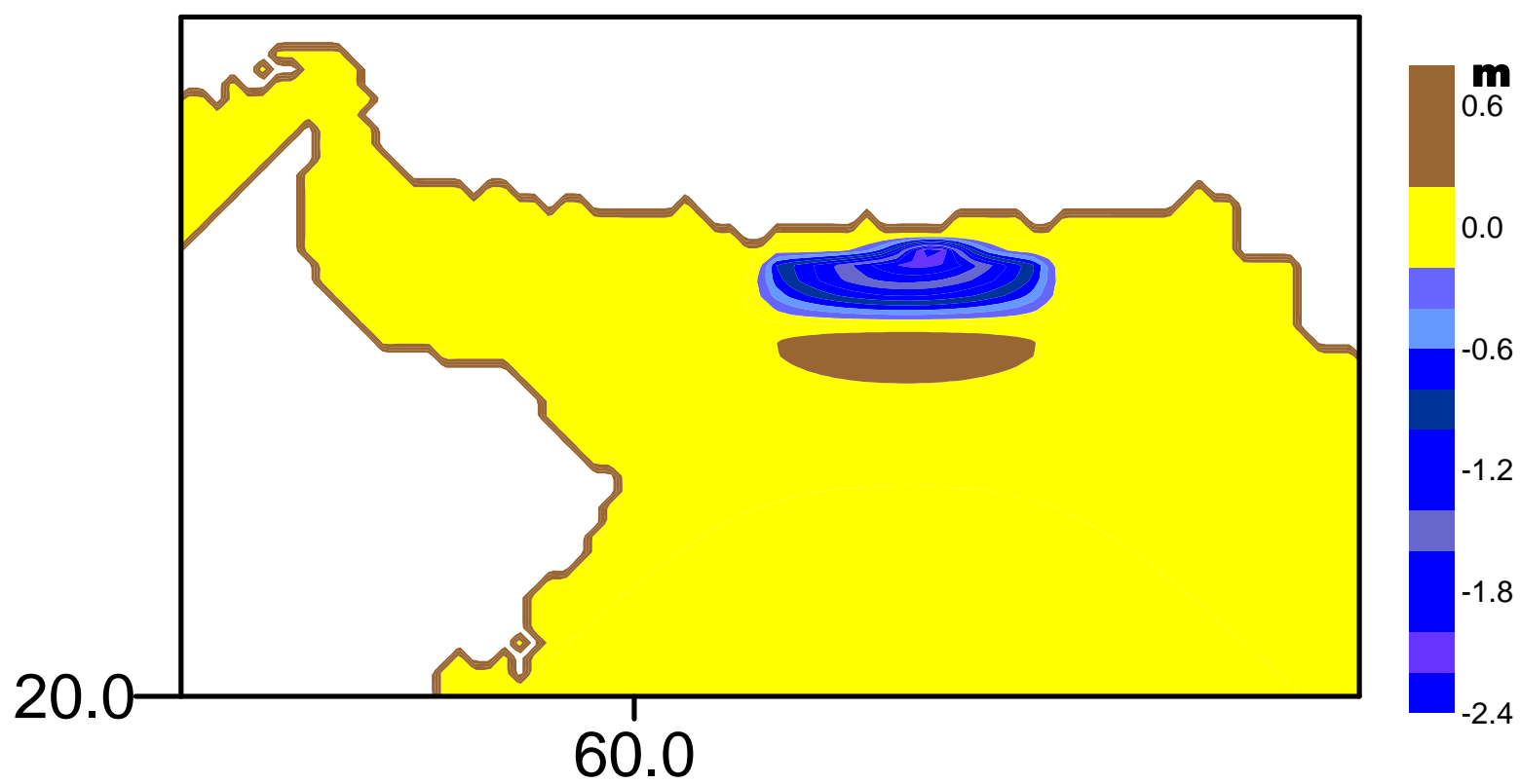

Figure A4. Static fault displacement generated by an earthquake occurring at the Makran tsunamigenic zone, which is used for modelling the worst-case scenario, with parameters listed in Table 5, but for a strike equal to $280^{\circ}$.

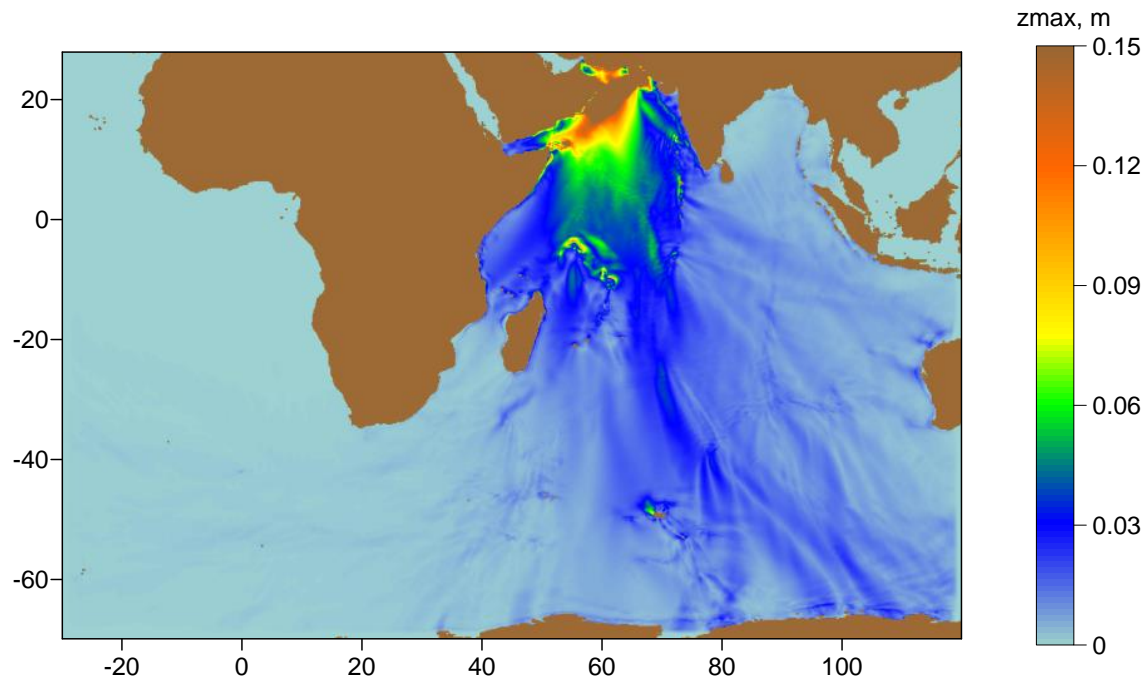

Figure A5 Estimated maximum surface elevation owing to a worst-case scenario earthquake occurring in the Makran tsunamigenic zone, with homogeneous seismic slip, and fault strike of $280^{\circ}$. The earthquake parameters are listed in Table 5. Triangles are as in Figure A1-1. 


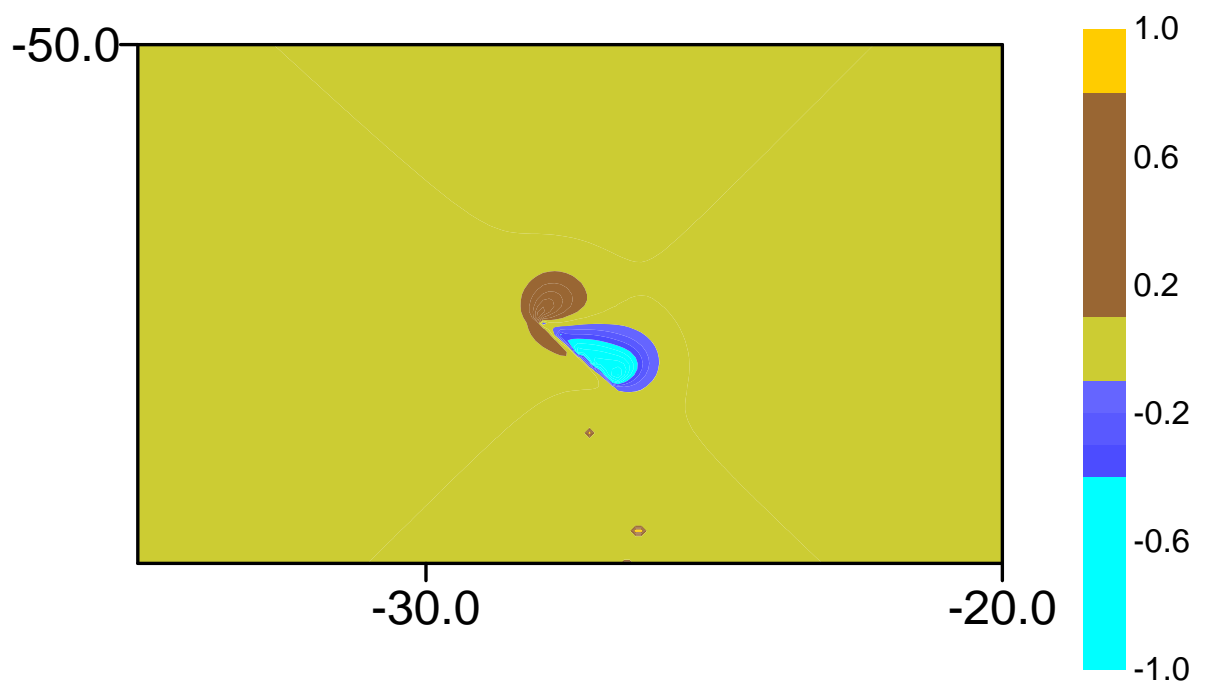

Figure A6. Static fault displacement of the South Sandwich Islands earthquake used as an initial condition for worst scenario 1 . The earthquake parameters are listed in Table 5, with earthquake fault strike of $130^{\circ}$.

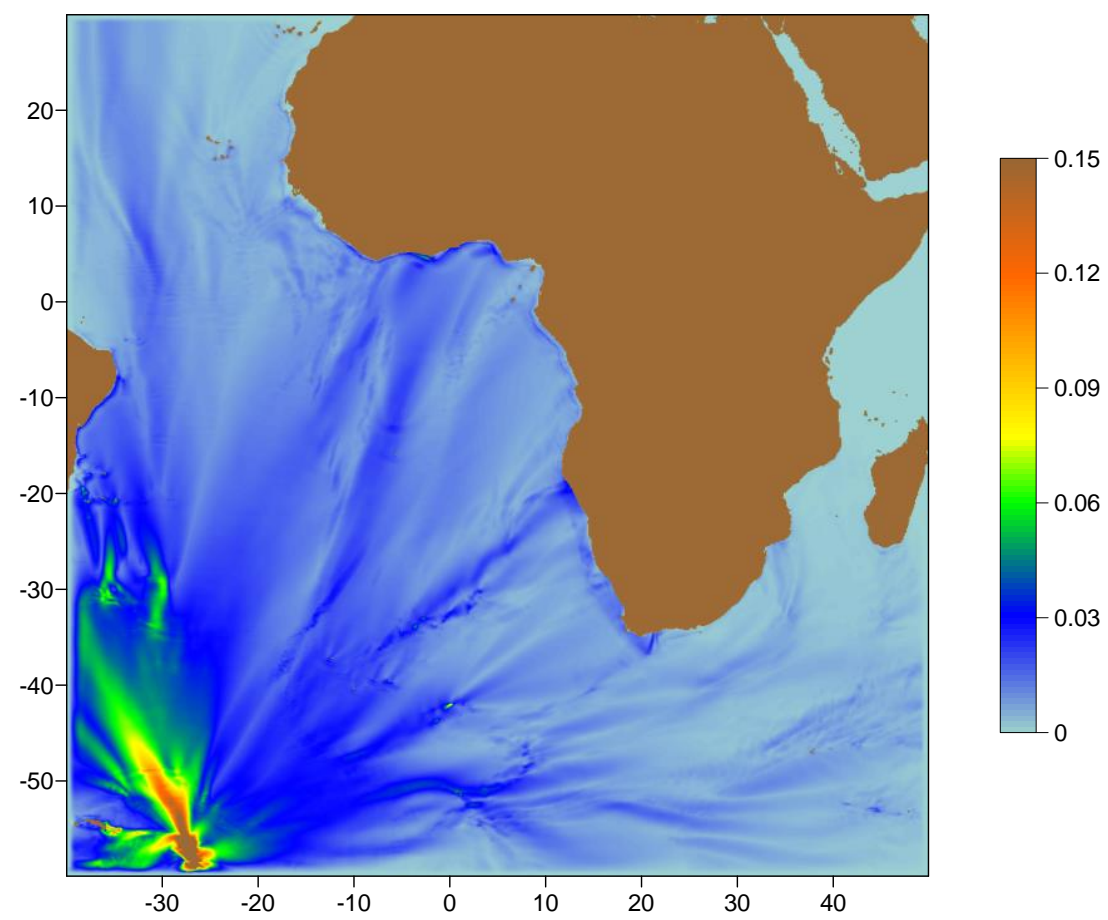

Figure A7. Estimated maximum surface elevation (m) owing to worst scenario 1 for the South Sandwich Islands earthquake, with homogeneous seismic slip and fault strike equal to $130^{\circ}$. The earthquake parameters are listed in Table 5. Triangles are as in Figure A1-1. 